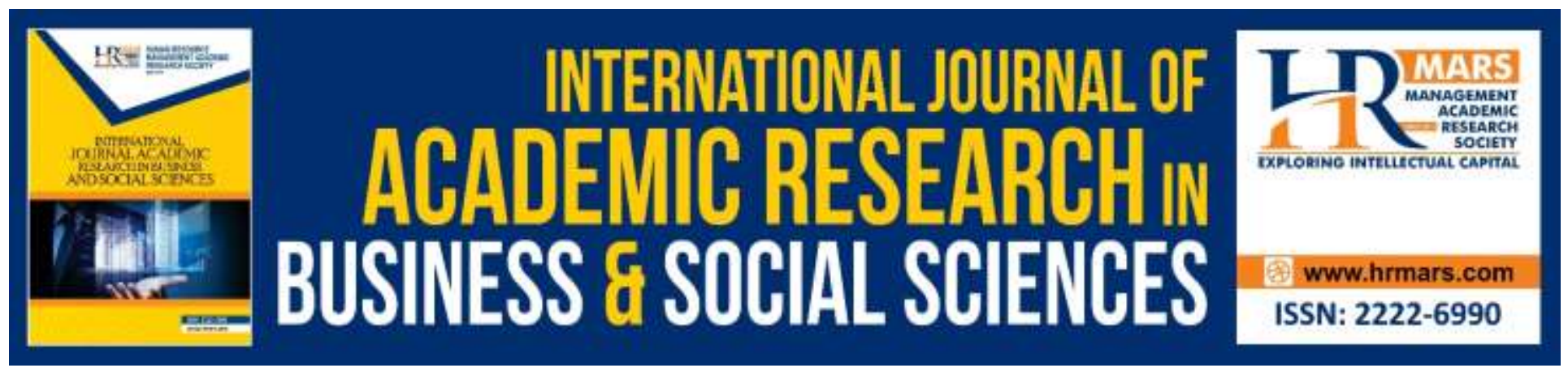

\title{
Reading Strategy Use among Good and Poor Primary English as a Second Language Learners
}

Christina Kiu Siaw Ling, Hamidah Yamat

To Link this Article: http://dx.doi.org/10.6007/IJARBSS/v10-i1/6853

DOI:10.6007/IJARBSS/v10-i1/6853

Received: 20 December 2019, Revised: 03 January 2020, Accepted: 18 January 2020

Published Online: 29 January 2020

In-Text Citation: (Kiu \& Yamat, 2020)

To Cite this Article: Kiu, C. S. L., \& Yamat, H. (2020). Reading Strategy Use among Good and Poor Primary English as a Second Language Learners. International Journal of Academic Research in Business and Social Sciences, 10(1), 318-330.

Copyright: (c) 2020 The Author(s)

Published by Human Resource Management Academic Research Society (www.hrmars.com)

This article is published under the Creative Commons Attribution (CC BY 4.0) license. Anyone may reproduce, distribute, translate and create derivative works of this article (for both commercial and non-commercial purposes), subject to full attribution to the original publication and authors. The full terms of this license may be seen

at: http://creativecommons.org/licences/by/4.0/legalcode

Vol. 10, No. 1, 2020, Pg. 318 - 330

http://hrmars.com/index.php/pages/detail/IJARBSS

JOURNAL HOMEPAGE

Full Terms \& Conditions of access and use can be found at http://hrmars.com/index.php/pages/detail/publication-ethics 


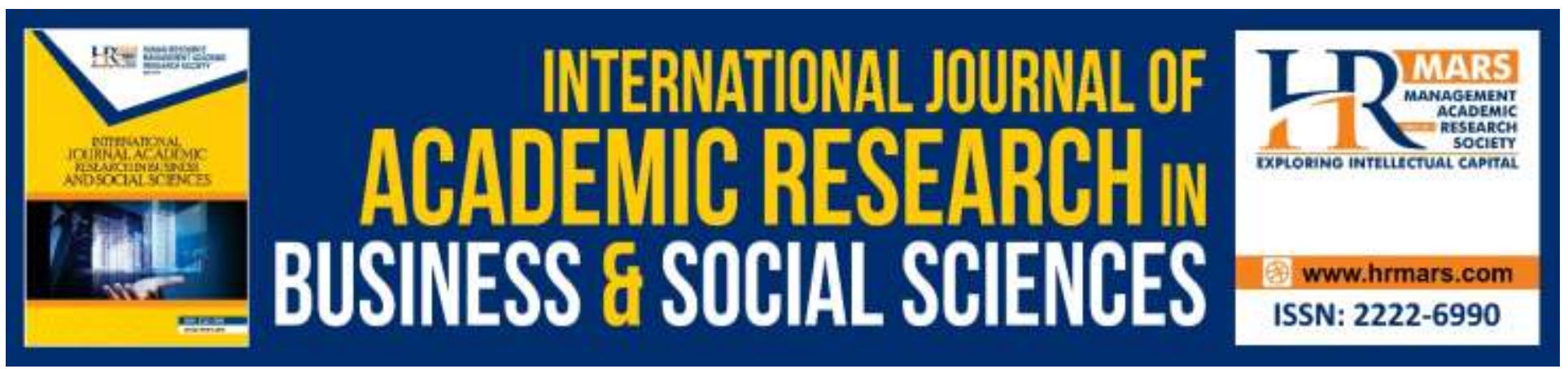

\title{
Reading Strategy Use among Good and Poor Primary English as a Second Language Learners
}

\author{
Christina Kiu Siaw Ling ${ }^{1,2}$, Hamidah Yamat ${ }^{2}$ \\ SK Nanga Tada, Kanowit, Sarawak, Malaysia ${ }^{1}$, Faculty of Education, Universiti Kebangsaan Malaysia ${ }^{2}$ \\ Email: christinakiu@gmail.com ${ }^{1}$
}

\begin{abstract}
Studies have shown that language learning strategies (LLS) assist English as a second language (ESL) learners in their language learning process. Nevertheless, there are still a worrying number of students who are not successful as ESL learners; particularly in rural areas. Thus, the objective of this preliminary study was to identify and compare the reading strategies employed by good and poor primary school ESL students. 38 Level 2 students from a rural school in Sarawak, Malaysia were involved in the study. Data was collected using the Young Learners' Language Strategy Use Survey that was modified from Cohen and Oxford's. The data were then analysed using descriptive analyses through the use of frequency, percentage and mean. The results showed that the good learners were inclined to use reading strategies more frequently than poor learners. Interestingly, the findings also revealed that the good language learners attempted to use the affective strategies most frequently while the poor language learners employed compensation strategies. The findings have significant implications for research on LLS for good and poor ESL learners as well as teachers' classroom instruction. Recognising the differences in the learners and understanding which LLS both good and poor learners employed more frequently and less frequently will help the teachers in tailoring their instruction according to students' needs in order to help them become more successful learners. Further studies could explore the factors that boost or hinder the use of LLS among the learners in the language learning process through think-aloud protocol to have a better understanding of reasons leading to the differences in LLS use between good and poor learners.
\end{abstract}

Keywords: Language Learning Strategies, ESL, Reading Strategies, Good Learners, Poor Learners

\section{Introduction}

LLS is a powerful tool for language learning (O'Malley et al., 1985). Oxford (1990), Cohen (1998) and Chamot (2001) stated that employing LLS are able to lead to more effective language learning. Therefore, to be independent readers, students need to master reading strategies and skills. Research studies have consistently confirmed that reading strategies are very important in developing students' reading comprehension (Mahdavi \& Tensfeldt, 2013; Ahmadi et al., 2013; Zare \& Othman, 2013). However, students' inability to use reading strategy while reading has been 
identified as one of the reasons holding the students back from comprehending the text. According to Ortlieb et al. (2013), struggling readers do not employ any LLS regularly during reading, thus resulting in having difficulty in comprehension. Many students struggle in their reading as they are unaware of or do not have effective strategies to comprehend English reading materials. Thus, lack of reading strategies has led to students having problems in reading comprehension.

Many researchers had looked into the reasons leading to certain language learners learning faster than other learners, and resulting in the wide gap in the English language competency among the learners. Although a lot of studies had been carried out to investigate the robust link between the learners' proficiency level and their strategy use in learning ESL (Huang \& Nisbet, 2014; Kayaoğlu, 2013), there is very little research that targeted LLS, specifically reading strategies employed by good and poor learners in the Malaysian primary schools that are situated at outskirts areas. Another issue in reading among ESL learners was that due to students' passiveness and reluctance to express their thoughts and views, it caused difficulty for ESL teachers to monitor and assess the students' understanding in the teaching and learning, especially during reading activities. Many ESL and EFL students were very reluctant to express their thoughts and views in English (Ansari, 2015; Nasruloh, 2013; Sundari, 2017). Similarly, in the context of this study, most of the students were found to be more passive, compliant and unreflective rote learners. As the learners played the role as passive participators in the teaching and learning activities, this had led to difficulty in knowing how these learners approached a reading text and which reading strategies they had mastered or were still lacked. In search for an answer to this issue, this study aims to identify reading strategies and the types of language learning strategies employed by ESL learners of different proficiency levels in Malaysian rural primary school in learning English language. Rubin (1975) opined that knowledge about LLS use will reduce the gap exists between the good and the poor language learners.

\section{Literature Review}

\section{Language Learning Strategies}

Wenden (1987) describes LLS as "techniques, tactics, potentially conscious plans, consciously employed operations, learning skills, basic skills, functional skills, cognitive abilities, language processing strategies, problem-solving procedures" (p7). Bialystok's (1978) definition of the purpose of LLS focuses on enhancing language competence whereas Chamot's (1987) on facilitating language learning. Another description of LLS is the learners' planning process for facilitating their own acquisition, storage, retrieval or usage of information in language learning (O'Malley et al., 1985; Oxford \& Crookall, 1989). Oxford (1990) further expands the definition of LLS as "specific actions taken by the learner to make learning easier, faster, more enjoyable, more self-directed, more effective, and more transferable to new situations" (p.8). There are various definitions proposed to describe LLS.

Many researchers such as Tarone (1980), Rubin (1987), O'Malley and Chamot (1990), Oxford (1990), Stern (1992) as well as Cohen (1998) have classified LLS. Thus, there are various distinct LLS taxonomies. In order to better understand the classification of LLS, the major and significant strategy taxonomies will be highlighted below. LLS taxonomy by O'Malley and Chamot (1990) had received considerable attention as it distinguishes LLS into three different types, which include cognitive, metacognitive and socio-affective. A key distinction made by Oxford (1990) is that she categorised 
INTERNATIONAL JOURNAL OF ACADEMIC RESEARCH IN BUSINESS AND SOCIAL SCIENCES

Vol. 10, No. 1, Jan, 2020, E-ISSN: 2222-6990 C 2020 HRMARS

LLS into two broad categories which are direct and indirect strategies. Oxford (1990) further classified the strategies into six subcategories, namely memory, cognitive and compensation strategies under direct strategies, as well as metacognitive, affective and social strategies under indirect strategies.

\section{Language Learners}

LLS has been one of the subjects many researchers looked into as LLS plays a very vital role in helping the researchers to understand the language strategies and skills that learners develop in learning ESL. Many studies have frequently examined the relationship between ESL learners' proficiency levels and their strategy use (Bialystok, 1978; Eslinger, 2000; Kayaoğlu, 2013; Rubin, 1975; Vann \& Abraham, 1990). The findings from these studies showed that there is generally a link between learners' English proficiency level and their strategy use.

Many researchers have investigated successful language learners and the language learning process. It has been argued that the successful language learners indeed differ from the less successful learners in their approach, study habits, preference, persistence and language behaviour (Rubin, 1975; Stern, 1975). Studies have shown that successful language learners use more LLS than less successful learners do (Chamot, 1987; Rubin, 1975; Naiman et al., 1978; Oxford, 1989, 1993). The major finding by Oxford (1989) suggested that good language learners cope with their own learning process through different type of strategies such as memory, cognitive, compensation, metacognitive, affective and social strategies. Furthermore, the findings by a study conducted by Anderson (2005) showed that successful language learners possess various LLS ready to be employed in different tasks and occasions.

Many studies have been carried to investigate successful language learners and the reasons leading to effective language learning. On the other hand, there were also a few researchers who surveyed less successful language learners. Findings from the studies by Hosenfeld (1977), Abraham and Vann (1987), Nyikos (1987) as well as Chamot and Kupper (1989) showed a few distinct features regarding less successful learners. It was noticed that less successful learners do not know what strategies they are using, and they cannot explain the strategies as they might use them unconsciously. In addition, less successful learners have limited number of strategies. Hence, they use fewer strategies than more successful learners, and they only apply the same strategies repeatedly. Further, less successful learners may have a substantial number of strategies, however they lack coherence while employing the strategies. These students apply the strategies randomly without targeting the strategies to the task.

Although many researches have been carried out to examine the relationship between learners' proficiency level and their LLS use, there was still very little research specifically targeted reading strategy use of young language learners in rural school context. Hence, more research is needed to identify and compare the reading strategies used by both successful and less successful primary ESL learners in Malaysian rural schools.

\section{Methodology}

As the purpose of the study is to identify reading strategies and the types of LLS employed by learners of different proficiency levels in learning ESL, the research design that suits the purpose of this study is quantitative study. A quantitative approach was chosen because this approach enabled the 
researcher to examine the frequency of ESL learners' use of reading strategies. A survey design is a well-suited methodology to be adopted in this study as it helps to generate quantifiable data of learners' reading strategy use.

The study was conducted at a national primary school which is located at the outskirts area of Sarawak, Malaysia. There was only one class for each year. Therefore, all the classes comprised of mixed-ability students. In this study, a total of 36 students from Level 2 classes, which include Year 4, 5 and 6 primary students were chosen to be the samples through purposive sampling method. The age of the samples in the study ranged from 10 to 12 years old. The first language of these respondents is Iban language and they had been exposed to ESL for four to six years in this school. These respondents were divided into good and poor proficiency levels, with 18 students in each proficiency level in English language. Table 1 shows the overview of the sample involved in this study. In order to categorise these respondents as 'good' and 'poor' learners, all the three ESL teachers who were teaching them English were asked to identify successful and unsuccessful learners in their classes based on a few criteria: classroom observation, student participation and performance as well as their progress in learning ESL. The categorisation of the respondents was later checked and confirmed with their monthly and term exam results in English language.

Table 1. Overview of the Sample of the Study

\begin{tabular}{cccc}
\hline Year & \multicolumn{2}{c}{ Number of Sample } & Total \\
\hline & Good learners & Poor leaners & \\
Four & 6 & 6 & 12 \\
Five & 7 & 5 & 12 \\
Six & 5 & 7 & 12 \\
\hline Total & 18 & 18 & 36 \\
\hline
\end{tabular}

Cohen and Oxford's (2002) Young Learners' Language Strategy Use Survey was used to assess LLS use in this study. This 76-item questionnaire examines LLS use in different language skills which include listening, speaking, reading and writing, as well as other language features such as vocabulary and translation. The questionnaire was modified based on the context of this study to produce the data that the present study required. Only the section on reading skill was used in this study as the focus of this study was to identify learners' reading strategy use. Thus, the adapted version of Young Learners' Language Strategy Use Survey consists of 16 statements concerning reading strategies. Each statement was given in the form of a 3-point Likert scale ranging from 1 for "The statement isn't like me", 2 for "The statement is somewhat like me" and 3 for "The statement really describes me" to show the frequency of the language learning strategy use. For easier identification of the category of the respondents - 'good learners' or 'poor learners' during data input for further analysis of the data, the instrument includes a column on demographic information regarding respondents' proficiency level. However, to avoid the sensitivity of labelling the students as 'good' and 'poor' learners, the instrument uses the term 'Group $A$ ' to indicate good learners and 'Group B' to indicate 'poor learners'.

In the present study, a series of descriptive analyses were performed over the quantitative data in order to summarise the data obtained from the questionnaire. Hence, descriptive statistics, 
INTERNATIONAL JOURNAL OF ACADEMIC RESEARCH IN BUSINESS AND SOCIAL SCIENCES Vol. 10, No. 1, Jan, 2020, E-ISSN: 2222-6990 @ 2020 HRMARS

which include frequencies, percentages and means were calculated as these analyses were found the most suitable to present the main features of the quantitative data. Conducting these analyses could help the researchers to determine which reading strategies were most and least frequently employed by the good and poor learners in learning ESL. Learners' reading strategy use were analysed based on the category of learners' proficiency level - good and poor as well as the frequency of strategy use - high, moderate and low.

Table 2. Frequency Rating for Learners' Strategy Use

\begin{tabular}{llc}
\hline \multicolumn{1}{c}{ Frequency of Use } & \multicolumn{1}{c}{ Responses } & Mean Scores \\
\hline High & The statement really describes me. & $2.35-3.00$ \\
Moderate & The statement is somewhat like me. & $1.68-2.34$ \\
Low & The statement isn't like me. & $1.00-1.67$ \\
\hline
\end{tabular}

Table 2 shows the frequency ratings for learners' strategy use. An interpretation mean score was employed to determine the frequency of reading strategy use. Students' responses were categorised into high, moderate and low frequency use of LLS. In this 3-point Likert scale, an average score of 1.00 to 1.67 is defined as low use; 1.68 to 2.34 as moderate use; and 2.35 to 3.00 as high use.

After obtaining permission to conduct the survey, the researcher started collecting data through administering the questionnaires. As the respondents are divided into two categories according to their proficiency levels, the questionnaire was administered to the respondents in two groups with the help of the three English language teachers who were teaching the students. Before the administration, instructions were provided in Malay and Iban language to make sure the respondents truly understand the purpose of conducting the survey. To ensure that all participants were listening to the directions and answering the questionnaire, the researcher read each statement aloud. Then, each statement in the questionnaire was also translated and explained in the learners' mother tongue, Iban language one by one, so that students had a better understanding of all the statements, hence avoid the misinterpretation of the items in the survey by the respondents. The researcher paused and allowed time for the respondents to mark their own answers for each reading strategy according to the frequency of their own strategy use. The respondents completed the questionnaire in approximately 10 minutes under the supervision of the researcher and the English language teachers. The completed questionnaires were then collected and sorted into two sets according to the respondents' proficiency levels.

The concepts of validity and reliability are core issues in ensuring the quality of the data collected for this survey research. There were a few aspects taken into considerations while planning and administrating the survey in order to make sure that the survey could yield high quality data. In order to enhance the face validity and content validity of the questionnaire, all the items in the questionnaire were reviewed by a panel of English language teachers who were teaching these Level 2 students. They checked and made sure that the wording for each statement uses simple English, so that the respondents could understand all the statements and provide meaningful answers. Besides that, the questionnaire items were checked to ensure that they are clear and unambiguous, and they would not confuse the respondents. As for the format structure of the questionnaire, each statement in the questionnaire is followed by a limited number of response options. This questionnaire does 
not use a scale with many Likert-like options, whereby each statement was only given a 3-point Likert scale. Considering the fact that participants of this study, which were still young ESL learners at the age of 10 to 12, were not fully developed cognitively and metacognitively, therefore instruments that use many Likert-like options such as a five-point Likert scale would possibly cause these young learners to have difficulty in deciding on the scale that accurately reflects their judgements or attitudes. Gelman and Baillargeon (1983), Terzidis (2018), Umaru, Aguda and Davies (2018) argued that asking younger children to respond on a 5-point scale may be beyond their capability.

As for the content validity, the same panel of English language teachers were asked to check the questionnaire to ensure that the items included were able to reflect the issue that was being researched - reading strategy use. With the use of questionnaire that had been checked by the experts, hence the data collected could provide a complete picture of the learners' reading strategy use, and the conclusion being drawn would be more accurate. The reliability check of the instrument was done through the use of SPSS software. The data collected were analysed and the internal consistency reliability of the questionnaire was excellent at .965 on Cronbach alpha for both good and poor learners. This shows that the questionnaire used in this study was reliable, whereby the measurements were consistent from individual to individual surveyed.

\section{Findings and Discussion}

This present study is preliminary research on the reading strategy used by learners of different proficiency levels. In order to compare reading strategy employed by the good and poor learners, the detailed descriptive statistics for each response in questionnaire is tabulated below. 
INTERNATIONAL JOURNAL OF ACADEMIC RESEARCH IN BUSINESS AND SOCIAL SCIENCES

Vol. 10, No. 1, Jan, 2020, E-ISSN: 2222-6990 @ 2020 HRMARS

Table 3. An analysis of Learners' Reading Strategy Use

\begin{tabular}{|c|c|c|c|c|c|c|}
\hline \multirow[t]{2}{*}{ No } & \multirow[t]{2}{*}{ Reading Strategy } & & \multicolumn{3}{|c|}{ Frequency of Strategy Use (\%) } & \multirow[t]{2}{*}{ Mean } \\
\hline & & & High & Moderate & Low & \\
\hline \multirow[t]{2}{*}{1} & I read a lot in the language. & Good & 22.22 & 72.22 & 5.56 & 2.17 \\
\hline & & Poor & 0.00 & 55.56 & 44.44 & 1.56 \\
\hline \multirow[t]{2}{*}{2} & I read for fun in the language. & Good & 61.11 & 27.78 & 11.11 & 2.50 \\
\hline & & Poor & 22.22 & 55.56 & 22.22 & 2.00 \\
\hline \multirow[t]{2}{*}{3} & I find things to read that interest & Good & 83.33 & 11.11 & 5.56 & 2.78 \\
\hline & me. & Poor & 11.11 & 50.00 & 38.89 & 1.72 \\
\hline \multirow[t]{2}{*}{4} & I look for things to read that are & Good & 83.33 & 16.67 & 0.00 & 2.83 \\
\hline & not too hard. & Poor & 27.78 & 55.56 & 16.67 & 2.11 \\
\hline \multirow[t]{2}{*}{5} & I skim over a reading to get the & Good & 16.67 & 50.00 & 33.33 & 1.83 \\
\hline & main idea. & Poor & 0.00 & 22.22 & 77.78 & 1.22 \\
\hline \multirow[t]{2}{*}{6} & I look for important facts. & Good & 11.11 & 22.22 & 66.67 & 1.44 \\
\hline & & Poor & 0.00 & 33.33 & 66.67 & 1.33 \\
\hline \multirow[t]{2}{*}{7} & I read things more than once. & Good & 5.56 & 55.56 & 38.89 & 1.67 \\
\hline & & Poor & 5.56 & 55.56 & 38.89 & 1.67 \\
\hline \multirow[t]{2}{*}{8} & I look at pictures and what is & Good & 66.67 & 33.33 & 0.00 & 2.67 \\
\hline & under the pictures. & Poor & 33.33 & 33.33 & 33.33 & 2.00 \\
\hline \multirow[t]{2}{*}{9} & I look at the headings. & Good & 83.33 & 11.11 & 5.56 & 2.78 \\
\hline & & Poor & 27.78 & 38.89 & 33.33 & 1.94 \\
\hline \multirow[t]{2}{*}{10} & I think about what will come next & Good & 44.44 & 27.78 & 27.78 & 2.17 \\
\hline & in the reading. & Poor & 5.56 & 11.11 & 83.33 & 1.22 \\
\hline \multirow[t]{2}{*}{11} & I stop to think about what I just & Good & 55.56 & 16.67 & 27.78 & 2.28 \\
\hline & read. & Poor & 0.00 & 5.56 & 94.44 & 1.06 \\
\hline \multirow[t]{2}{*}{12} & I underline parts that seem & Good & 16.67 & 27.78 & 55.56 & 1.61 \\
\hline & important. & Poor & 5.56 & 38.89 & 55.56 & 1.50 \\
\hline \multirow[t]{2}{*}{13} & I mark the reading in different & Good & 16.67 & 33.33 & 50.00 & 1.67 \\
\hline & colours to help me understand. & Poor & 5.56 & 50.00 & 44.44 & 1.61 \\
\hline \multirow[t]{2}{*}{14} & I check to see how much I & Good & 33.33 & 44.44 & 22.22 & 2.11 \\
\hline & understood. & Poor & 5.56 & 27.78 & 66.67 & 1.39 \\
\hline \multirow[t]{2}{*}{15} & I guess the meaning by using clues & Good & 44.44 & 38.89 & 16.67 & 2.28 \\
\hline & from other parts of the passage. & Poor & 0.00 & 61.11 & 38.89 & 1.61 \\
\hline \multirow[t]{2}{*}{16} & I use a dictionary to find the & Good & 72.22 & 16.67 & 11.11 & 2.61 \\
\hline & meaning. & Poor & 77.78 & 11.11 & 11.11 & 2.67 \\
\hline \multirow{2}{*}{\multicolumn{2}{|c|}{ Overall Strategy }} & Good & 44.79 & 31.60 & 23.61 & 2.21 \\
\hline & & Poor & 14.24 & 37.85 & 47.92 & 1.66 \\
\hline
\end{tabular}

Table 3 above provides the analysis of learners' overall strategy use. The results showed that good learners differed significantly from poor learners in LLS use. Good learners employed $44.79 \%$ of the reading strategies frequently. On the other hand, poor learners only used $14.24 \%$ of the reading 
strategies frequently. This reveals that good learners in this school are generally high frequency users of reading strategy while poor learners are low strategy users. The overall strategy mean score for good learners is higher, 2.21 compared to poor learners with 1.66. In addition, the mean scores for all the reading strategies are higher for good learners compared to poor learners with the exception for item no. 7 and item no. 16. This indicates that the good learners use the above mentioned reading strategies more often than poor leaners and differ only in reading things more than once for understanding as well as using dictionary to find the meaning. In other words, poor learners use dictionary more frequently as compared to good learners when they encounter words that they do not understand.

The reading strategies that good learners employ most frequently are finding reading materials that interest them, looking for materials that are not too hard as well as looking at the headings while reading, with $83.33 \%$ high frequency of strategy use for all these strategies. Among these three strategies, the strategy with highest mean score, 2.83 is looking for things to read that are not too hard. On the other hand, good learners use the reading strategy - looking for important facts least frequently, with the lowest mean score, 1.44 among all the other reading strategies. $66.67 \%$ of good learners show low frequency of use for that reading strategy whereas only $11.11 \%$ of good learners show high frequency of use for the strategy - looking for important facts while reading.

As for the poor learners, the reading strategy that is employed most frequently is using a dictionary to find the meaning, with the highest mean score of 2.67 among all the reading strategies. $\mathbf{7 7 . 7 8 \%}$ of poor learners show high frequency of use for this strategy - using a dictionary. Stop to think about what they have just read is the reading strategy that poor learners use least frequently, with the lowest mean score of 1.06 . While $94.44 \%$ of poor learners show low frequency use for this strategy, none of them show high frequency of strategy use, indicating that poor learners rarely stop to monitor and assess their own comprehension during reading. This is also the strategy that varies the most between the good learners and the poor learners, with the highest difference in mean scores, 1.22. This indicates that there is a huge difference between learners of the two different proficiency levels in employing this strategy.

Besides that, the results revealed that the mean scores for one of the reading strategies, which is reading things more than once, is the same for both good learners and poor learners, indicating all the learners regarding of their proficiency levels employ this strategy similarly. With the mean of score of 1.67 for the strategy use, it indicates that both good and poor learners rarely read things more than once.

Table 4. An analysis of Types of Strategy Use

\begin{tabular}{lllllll}
\hline \multirow{2}{*}{ Types of Strategy } & \multicolumn{2}{l}{ Good Learners } & \multicolumn{4}{l}{ Poor Learners } \\
\cline { 2 - 7 } & Mean & Frequency & Rank & Mean & Frequency & Rank \\
\hline Memory & 1.97 & Moderate & 5 & 1.36 & Low & 4 \\
Cognitive & 2.00 & Moderate & 4 & 1.60 & Low & 3 \\
Compensation & 2.44 & High & 2 & 2.14 & Moderate & 1 \\
Metacognitive & 2.14 & Moderate & 3 & 1.31 & Low & 5 \\
Affective & 2.57 & High & 1 & 1.85 & Moderate & 2 \\
\hline
\end{tabular}


Table 4 above provides the analysis of learners' strategy use in terms of types in accordance to Oxford's (1990) LLS taxonomy. The findings showed that the mean scores for all the five types of strategy are higher for good learners as compared to poor learners. This indicates that good learners use all the different types of strategy more frequently than poor learners in reading. Besides that, the findings also revealed that poor learners and good learners vary enormously in terms of the types of strategy employed during reading. Good learners employ the five types of LLS in a moderate to high use, with no low use in reading. For good learners' strategy use, the highest among the five dimensions was affective strategies, with a mean of 2.57. Another type of strategy that good learners also show high frequency of use is compensation strategy, with a mean of 2.44. This shows that good learners use affective and compensation strategies most frequently in reading. On the other hand, good learners employ memory strategy less frequently among all five types of strategies. Although memory strategy is the least frequently used strategy for good learners, the mean of 1.97 indicates that they still show moderate use of memory strategy in reading.

As for the poor learners, they employ the different types of LLS in a low to moderate use, with no high use while reading. The findings showed that poor learners use compensation strategy the most, with the mean of 2.14, whereas metacognitive strategy the least, with the mean of 1.31 , in reading. This finding revealed that poor learners often overcome knowledge constraints while reading through the use of dictionary or guessing the meanings intelligently. The low use of metacognitive strategy among poor learner's shows that they rarely self-monitor and self-evaluate during reading.

In short, the findings of this study revealed that good ESL learners in rural primary school are high frequency users of reading strategy while the poor learners are low strategy users. This result was consistent with the findings in other previous LLS studies even though most of the previous studies were carried in different contexts with secondary, university or even adult learners in different locality of the schools or institutions. The findings supported the study carried out by Embi et al. (2001); Mottan \& Shanmugam (2018) in which the results showed that good language learners possessed a greater use of LLS, thus more successful learners employed LLS far more frequently than less successful ones.

\section{Conclusion and Implications}

To conclude, poor ESL leaners employed significantly lesser reading strategies as compared to the successful language learners. These poor learners struggled in their reading as they were unaware of or did not have effective reading strategies to comprehend English reading materials. Besides that, as the ESL learners in the study were passive and reluctant to verbalise their thoughts to express what they knew and what they did not, this study had helped the researchers who were also the ESL teachers to have a better understanding of which reading strategies were employed more frequently and less frequently by both good and poor learners. It can be concluded that the reading strategies employed by good and poor language learners varied differently, whereby the good language learners attempted to use the affective strategies most frequently while the poor language learners employed compensation strategies.

These knowledge of LLS can significantly contribute to the development of the ESL teaching and learning. This study proposes the following implications for ESL teachers in Malaysian primary 
schools, especially those in outskirts areas. It is important for ESL teachers to be conscious of the existence of LLS in all learners, regardless of their age or proficiency levels. Teachers need to know the reading strategies the ESL learners are good at or they are struggling with. Teachers should also recognise the differences in the learners because understanding which LLS both good and poor learners employed more frequently and less frequently will help the teachers in tailoring their instruction according to students' needs. There is no doubt that there is a robust link between the use of LLS and learners' proficiency level. Therefore, strategy instruction is needed for the less successful students to help them become more successful learners. Teachers need to help struggling readers to learn and develop the reading strategies they need for higher level reading, so that the students can become avid and independent readers. Having ESL teachers to help struggling readers can make all the difference as these reading strategies can be taught. Thus, language teachers should create learning contexts that allow learners to use and also discover a wider range of reading strategies. Language learners need to be exposed and taught to employ these strategies to enhance their language learning attainment. Hence, the worrying number of students who are still not successful as ESL learners; particularly in rural areas could be reduced, and thereby close the wide language competence gap between the good and poor ESL learners.

Besides that, it is essential for the learners to be conscious of the importance of LLS and the reading strategies that they possess. Hence, ESL teachers could work on increasing the learners' awareness in LLS to equip and facilitate them with more meaningful language learning experiences. Teachers could come up with language activities that provide opportunities for the learners to share their reading strategies with the others, so that they could learn from each other. For instance, poor language learners learn from the good language learners the strategies that assist them in learning English language.

LLS possess countless potential in second language acquisition. This study is only a very preliminary step in improving the knowledge of the reading strategies that good and poor ESL learners possess and use during reading, and the potential relationships between learners' proficiency level and their strategy use. A more comprehensive study is needed to clarify the potential alternative interpretations in this preliminary study on reading strategy use. Further studies could also explore the factors that boost or hinder the use of LLS among the learners through in the language learning process.

\section{References}

Abrahma, R., \& Vann, R. (1987). Strategies of two language learners: A case study. In A. Wenden \& J. Rubin (Eds.). Learner Strategies in Language Learning (pp. 85-102). Cliffs, NJ: Englewood Prentice Hall.

Ahmadi, M. R., Ismail, H. N., \& Abdullah, M. K. K. (2013). The importance of metacognitive reading strategy awareness in reading comprehension. English Language Teaching, 6(10), 235-244.

Ansari, M. S. (2015). Speaking Anxiety in ESL/EFL Classrooms: A Holistic Approach and Practical Study. International Journal of Educational Investigations, 2(4), 38-46.

Anderson, N. J. (2005). L2 learning strategies. In E. Hinkel (Ed.). Handbook of research in second language teaching and learning (pp. 757-771). Mahwah, NJ: Lawrence Erlbaum Associates. Bialystok, E. (1978). A theoretical model of second language learning. Language Learning, 28, 69-83. 
INTERNATIONAL JOURNAL OF ACADEMIC RESEARCH IN BUSINESS AND SOCIAL SCIENCES

Vol. 10, No. 1, Jan, 2020, E-ISSN: 2222-6990 @ 2020 HRMARS

Chamot, A. (1987). The learning strategies of ESL students. In A. Wenden, A \& J. Rubin (Eds.). Learner Strategies in Language Learning (pp. 85-102). Cliffs, NJ: Englewood Prentice Hall.

Chamot, A. (2001). The role of learning strategies in second language acquisition. In M. P. Breen (Ed.). Learner contributions to language learning: New directions in research (pp. 25-43). Harlow, England: Longman.

Chamot, A., \& Kupper, L. (1989). Learning strategies in foreign language instruction. Foreign Language Annuals, 22, 13-24.

Cohen, A. D. (1998). Strategies in learning and using a second language. New York: Addison Wesley Longman Inc.

Cohen, A. D., \& Oxford, R. L. (2002). Young Learners' Language Strategy Use Survey. Minneapolis, MN: Center for Advanced Research on Language Acquisition, University of Minnesota.

Embi, M. A., Long, J., \& Hamzah, M. I. (2001). Language learning strategies employed by secondary school students in Malaysia. Jurnal Pendidikan, 26, 2-3.

Eslinger, C. E. (2000). A more responsive mind: A study of learning strategy adaptation among culturally diverse ESL students (Unpublished master's thesis). Brigham Young University, Utah.

Gelman, R., \& Baillargeon, R. (1983). A review of some Piagetian concepts. In J. H. Flavell, \& E. M. Markman (Eds.). Handbook of child psychology: Vol. 3 Cognitive Development (pp. 167-230). New York: Wiley.

Hosenfeld, C. (1977). A preliminary investigation of the reading strategies of successful and nonsuccessful second language learners. System, 5, 116-123.

Huang, J., \& Nisbet, D. (2014). The relationship between reading proficiency and reading strategy use: A study of adult ESL learners. Journal of Adult Education, 43(2), 1-11.

Kayaoğlu, M. N. (2013). Poor and good learners' language beliefs and their influence on their language learning strategy use. Novitas-ROYAL, 7(1), 36-54.

Mahdavi, J. N., \& Tensfeldt, L. (2013). Untangling reading comprehension strategy instruction: Assisting struggling readers in the primary grades. Preventing School Failure: Alternative Education for Children and Youth, 57(2), 77-92.

Naiman, N., Frohlich, M., Stern, H. H., \& Todesco, A. (1978). The good language learner. Toronto, Ontario: Ontario Institute for Studies in Education.

Nasruloh, M. I. (2013). Teacher-Student Interaction in a Project-based Learning Classroom. Journal of English and Education 1(1), 142-153.

Nyikos, M. (1987). The effects of color and imagery as mnemonic devices on learning and retention of lexical items in German (Doctoral dissertation). Retrieved from: Proquest Dissertations \& Theses Full-Text (ATT 58160804).

O'Malley, J., \& Chamot, A. (1990). Learning strategies in second language acquisition. Cambridge: Cambridge University Press.

O’Malley, J. M., Chamot, A., Stewner-Manzanares, G., Kupper, L., \& Russo, R. (1985). Learning strategies used by beginning and intermediate ESL students. Language Learning, 35(1), 2146.

Ortlieb, E., Verlaan, W., \& Cheek, E. H. (2013). Vocabulary/Comprehension-based models of reading clinics. In E. Ortlieb \& E. H. Cheek (Eds.). Advanced literacy practices: From the clinic to the classroom (pp. 117-136). Bingley, UK: Emerald. 
INTERNATIONAL JOURNAL OF ACADEMIC RESEARCH IN BUSINESS AND SOCIAL SCIENCES

Vol. 10, No. 1, Jan, 2020, E-ISSN: 2222-6990 C 2020 HRMARS

Oxford, R. (1989). Use of language learning strategies: A synthesis of studies with implications for strategy training. System, 17(1), 235-247.

Oxford, R. (1990). Language learning strategies: What every teacher should know. New York: Newbury House Harper Collins.

Oxford, R. (1993). Language learning strategies in a nutshell: Update and ESL suggestions. TESOL Journal, 2(2), 18-22.

Oxford, R., \& Crookall, D. (1989). Language learning strategies: Methods, findings, and instructional implications. Modern Language Journal, 73, 404-419.

Rubin, J. (1975). What the 'good language learner' can teach us. TESOL Quarterly, 9(1), 41-51.

Rubin, J. (1987). Learner strategies: Theoretical assumptions, research history and typology. In A. Wenden \& J. Rubin (Eds.). Learner Strategies and Language Learning (pp. 15-29). Englewood Cliffs, NJ, Prentice Hall.

Stern, H. (1975). What can we learn from the good language learner? Canadian Modern Language Review, 31(3), 304-317.

Stern, H. (1992). Issues and options in language teaching. Oxford: Oxford University Press.

Sundari, H. (2017). Classroom Interaction in Teaching English as Foreign Language at Lower

Secondary Schools in Indonesia. Advances in Language and Literary Studies 8(6), 147-154.

Tarone, E. (1980). Communication strategies, foreigner talk, and repair in interlanguage. Language Learning, 30(2), 417-431.

Vann, R. J., \& Abraham, R. G. (1990). Strategies of unsuccessful language learners. TESOL Quarterly, 24(2), 177-198.

Wenden, A. L. (1987). Conceptual background and utility. In A. L. Wenden, \& J. Rubin (Eds.). Learner strategies in language learning (pp. 3-13). Englewood Cliffs, NJ: Prentice-Hall.

Mottan, K., \& Shanmugam, D. (2018). Role of Parents in Remedial Pupil's Academic Achievement. International Journal of Academic Research in Progressive Education and Development, 7(4), 166-178.

Terzidis, E. (2018). Stress in Primary School Principals of Pella Regional Unit. Multilingual Academic Journal of Education and Social Sciences, 6(1), 182-198 (in Greek).

Umaru, H., Aguda, N. A., Davies, N.O. (2018). The Effects of Exchange Rate Volatility on Economic Growth of West African English-Speaking Countries, International Journal of Academic Research in Accounting, Finance and Management Sciences 8 (4): 131-143.

Zare, P., \& Othman, M. (2013). The relationship between reading comprehension and reading strategy use among Malaysian ESL learners. International Journal of Humanities and Social Science, 3(13), 187-193. 